ACTA UNIVERSITATIS LODZIENSIS

FOLIA LITTERARIA POLONICA 1(39) 2017

http://dx.doi.org/10.18778/1505-9057.39.14

Mirosława Wielopolska-Szymura*

\title{
Radio dla zagranicy - od hard power do soft power w międzynarodowej nadawczości radiowej
}

Odkrycie elektryczności, wynalezienie telegrafu, a następnie detekcja i użycie fal radiowych stanowiły istotny przełom w procesach komunikacyjnych. Telegraf bez drutu - jak nazywano na początku radio - okazał się idealnym środkiem przekazu, zwłaszcza w odniesieniu do zamorskich terytoriów kolonialnych, których posiadaniem szczyciły się europejskie potęgi w pierwszych latach XX wieku. Pierwotnie radio nie było postrzegane jako ,pozytywka", towarzysz dnia codziennego, który umila czas - lecz przede wszystkim jako środek łączności zagranicznej i międzykontynentalnej. Wysiłki zmierzające do odkrywania natury fal radiowych we wczesnych latach istnienia medium skoncentrowane były na zapewnieniu łączności z zagranicznymi przedstawicielstwami danego państwa, z placówkami handlowymi otwierającymi swe biura poza granicami kraju, $\mathrm{z}$ morską flotą wojenną i handlową oraz $\mathrm{z}$ agencjami informacyjnymi. W tym czasie informacje przekazywano za pomocą różnych systemów kodowania znaków, jednak od lat 40. XIX wieku w powszechnym użyciu pojawił się alfabet Morse'a. W konsekwencji także łączność radiowa realizowana była przy jego użyciu. Mimo że próby transmisji głosu podejmowano już od początku XX wieku, do 1906 roku nie udawało się tego dokonać w sposób satysfakcjonujący z powodu stosowania nadajników iskrowych, które były źródłem drgań gasnących [iskra]. Nadawano za ich pomocą sygnał w sposób pulsacyjny, dlatego umożliwiały one wysyłanie go jedynie alfabetem Morse’a [impuls-kropka / impuls-kreska]. Do tego momentu fale radiowe służyły głównie jako przekaźnik informacji.

Pierwotną funkcją radia jest zatem funkcja informacyjna. Jednak, co warte podkreślenia, wychodziła ona poza wymiar czysto poznawczy. Radio stanowiło

* Dr, e-mail: miroslawa.wielopolska-szymura@us.edu.pl; Uniwersytet Śląski w Katowicach, Wydział Nauk Społecznych, Instytut Nauk Politycznych i Dziennikarstwa, Zakład Komunikowania Międzynarodowego i Systemów Medialnych; 40-007 Katowice, ul. Bankowa 11.

${ }^{1}$ Radio music box [ang.] - „radiowa pozytywka”, określenie zastosowane przez Davida Sarnoffa około 1916 r., dyrektora Radio Corporation of America [RCA], wizjonera, który chciał, aby radio nadawało głos i muzykę i służyło rozrywce, zamiast pozostać tylko radiotelegrafem. Zob. J. Wood, History of International Broadcasting, Peter Peregrinus Ltd., London 1994, s. 12. 
łącznik pomiędzy ludźmi, czasem decydujący o ich „być albo nie być”, jak pokazała historia statku RMS Titanic [1912 rok], gdy zbyt późne odebranie komunikatu radiowego o niebezpieczeństwie ograniczyło możliwość pomocy tonącym, czy wcześniej pancernika Generał-Admirał Apraksin, w którego uratowaniu na przełomie 1899-1900 roku pomogła aparatura nadawczo-odbiorcza Aleksandra Popowa. Radio umożliwiło, na większą skalę niż telegraf, komunikację ze światem oddalonym o tysiące kilometrów. Układanie kabli telegraficznych było czasochłonne, trudne logistycznie i technicznie oraz niezwykle kosztowne, natomiast budowa przybrzeżnych i lądowych masztów radiowych oraz wyposażenie centrów nadawczo-odbiorczych okazały się i łatwiejsze, i bardziej opłacalne.

W informowaniu unaoczniła się także natura polityczna radia, która przejawiała się głównie w formach sprawowania władzy na odległość - szybkie przekazywanie urzędnikom państwowym i podwładnym decyzji politycznych stanowiło o jej sprawności. Radio od początku - już jako „telegraf bez drutu” - stało się lepszym niż prasa przedłużeniem rządów. Prasa, głównie prywatna, mimo różnych form presji ze strony władz, nie dawała takiej możliwości oddziaływania na obywateli, dlatego przywódcy polityczni szczególnie upodobali sobie radiotelegraf. Oczywiście taką funkcję pełnił wcześniej telegraf optyczny [semafor] czy telegraf elektryczny; radio niejako odziedziczyło ją po swych ,antenatach”. Słusznie Paul Levinson władzę sprawowaną za pomocą radia nazywa „akustokracją", porównując ją do demokracji w starożytnej Grecji, której skuteczność „mierzono” zasięgiem słyszalności głosu².

Pionierom radiofonii nie wystarczał przekaz opierający się na alfabecie Morse'a, pragnęli na falach radiowych usłyszeć ludzki głos oraz muzykę, podobnie jak w telefonie skonstruowanym w 1870 roku. Telefon umożliwiał rozmówcy słuchanie innej osoby, która choć pozostająca w oddaleniu, wydawała się być blisko; czyniło to komunikację bardziej bezpośrednią i intymną. Telefonu używano nie tylko w komunikacji osobistej, ale także komercyjnej - popularne stały się telefoniczne bloki rozrywkowe 3 . Próby transmisji głosu przez „radio bez drutu” podejmowano wielokrotnie już na wczesnym etapie odkrywania właściwości nowego medium: podjął się tego m.in. Reginald Fessenden, który 23 grudnia 1900 roku dokonał transmisji swojego głosu, używając transmitera iskrowego z zainstalowanym mikrofonem węglowym [wynalezionym wcześniej przez Davida Hughesa $^{4}$ ] - wynalazek ten nazwano radiofonem [radiophone]. Jakość tej transmisji

${ }^{2}$ P. Levinson, Miękkie ostrze, czyli historia i przyszłość rewolucji informacyjnej, przekł. H. Jankowska, Wydawnictwo Muza SA, Warszawa 2006, s. 141.

${ }^{3}$ Pierwsza tego typu usługa to oferta francuskiego Théâtrophone w 1890 r.; w 1893 r. na Węgrzech został założony Telefon Hirmondó - oferujący najbardziej rozbudowane usługi rozrywki telefonicznej; w 1895 r. w Londynie powstał Electrophone, a w 1907 r. w USA utworzono Tellevent.

${ }^{4}$ David Edward Hughes [1831-1900] - brytyjsko-amerykański wynalazca, opatentował m.in. telegraf klawiszowy, tzw. telegraf Hughesa [1855 r.], zwany w Polsce juzem [zob. M. Adamkowicz, 
była bardzo słaba i Fessenden wiedział, że nie uda się osiągnąć lepszej, jeżeli będzie posługiwał się nadajnikiem iskrowym. W 1904 roku zlecił zbudowanie alternatora, który umożliwiłby nadawanie fal elektromagnetycznych w sposób ciągły [continuous wave] i modulowanie ludzkiego głosu poprzez mikrofon. Dzięki urządzeniu stworzonemu przez Ernsta Alexandersona, Fessenden w Wigilię 1906 roku w Brant Rock dokonał pierwszej słowno-muzycznej transmisji radiowej. Niedługo potem, w 1908 roku naukowiec Lee de Forest skonstruował triodę, za pomocą której udało się wzmocnić sygnał radiowy. Dzięki ,audionowi”, jak nazwał swoje urządzenie, można było emitować sygnał na większe odległości oraz usprawnić nadawanie słów i muzyki.

Radio, dzięki technicznym właściwościom, miało tę przewagę nad telefonem i wcześniejszym telegrafem, że przekazywało informacje od jednego nadawcy do nieograniczonej liczby odbiorców. W dodatku „Radio przybrało taką, a nie inną postać, ponieważ odbiór fal elektromagnetycznych transportujących elektronicznie zakodowanego «pasażera» - głos lub dźwięk - okazał się o wiele tańszy niż nadawanie"s, dzięki czemu umożliwiał objęcie swym zasięgiem całego narodu. $\mathrm{Z}$ tego powodu radio stało się medium tak chętnie wykorzystywanym przez władze: ,akustokracja” usprawniła działanie wszystkich form rządu, zarówno totalitarnych, jak i demokratycznych - jak podkreśla Levinson ${ }^{6}$. Z jednej strony nasuwają się przykłady propagandowego użycia radia przez Adolfa Hitlera, Benito Mussoliniego czy Józefa Stalina, z drugiej audycje radiowe „Rozmowy przy kominku" prezydenta Franklina D. Roosvelta ${ }^{7}$ czy wojenne przemówienia Winstona Churchilla, Charles'a de Gaulle'a i Stefana Starzyńskiego.

Zdolność do rządzenia za pomocą radia, możliwości, jakie ono dawało na morzu i lądzie, jego właściwości strategiczne wykorzystywane już od czasów II wojny burskiej w Afryce w latach $1899-1902^{8}$, podczas I oraz II wojny światowej, czyniły z radia narzędzie w polityce zagranicznej, strategiach wojskowych

Eksponaty z Muzeum Poczty Polskiej. Aparat zwany juzem czyli historia telegrafu Hughesa, http:// www.dziennikbaltycki.pl/artykul/970141,eksponaty-z-muzeum-poczty-polskiej-aparat-zwany-juzem-czyli-historia-telegrafu-hughesa,id,t.html, dostęp: 14.05.2016]; ponadto skonstruował pierwszy mikrofon węglowy [1878 r.], dzięki któremu ulepszono telefon A. Bella i który ułatwił rozwój telefonii [David Hughes, http://www.britannica.com/biography/David-Hughes, dostęp: 12.05.2016].

${ }_{6}^{5}$ P. Levinson, dz. cyt., s. 143.

${ }^{6}$ Tamże, s. 142.

${ }^{7}$ Pierwszą audycję z cyklu „Fireside Chat” nadano 12 marca 1933 r., natomiast ostatnią wyemitowano 12 czerwca 1944 r. Zob. Franklin D. Roosvelt Presidential Library and Museum, http:// docs.fdrlibrary.marist.edu/firesi90.html [dostęp: 14.05.2016].

${ }^{8}$ Walczący z Brytyjczykami Burowie planowali użycie urządzeń Marconiego, co ciekawe wyprodukowanych w Niemczech, a sprowadzonych z brytyjskiej filii fabryki Siemens Bros. \& Co - oficjalnie konkurenta Marconi Company. Sprzęt został zarekwirowany w Durbanie podczas kontroli celnej przez Brytyjczyków, którzy sami zrobili z niego użytek, podobnie jak z radiotelegrafów kupionych bezpośrednio w fabrykach Marconiego. Zob.: P.J. Nahin, The Science of Radio, Springer Science \& Business Media, New York 2001, s. 49. 
i stosunkach dyplomatycznych, jakie zaliczyć można do sfery hard power. Już w 1906 w Nauen [Niemcy] powstała pierwsza stacja łącząca się za pomocą alfabetu Morse'a z niemieckimi koloniami w Afryce. Drugą była stacja należąca do spółki Radio-France założona w 1921 roku w Sainte-Assise [Francja], która w zamian za licencję na nadawanie transoceaniczne miała obowiązek przesyłania korespondencji francuskich władz i urzędników do zamorskich terytoriów9 ${ }^{9}$. Pierwszą międzynarodową rozgłośnią, wykorzystującą możliwość nadawania głosu i muzyki był BBC Empire Service [obecnie BBC World Service] założony w 1927 roku, którego zadaniem było zapewnienie kontaktu pomiędzy brytyjskimi urzędnikami kolonialnymi a metropolią oraz pomoc w rozpowszechnianiu kultury brytyjskiej w świecie. W efekcie Imperium Brytyjskiemu udało się także wzmocnić swoje interesy ekonomiczne, dla których dobre relacje z kontrahentami i mieszkańcami obcych krajów były kluczowe. Kolejnym międzynarodowym radiem było Radio Moskwa, powstałe w 1929 roku, które nadawało audycje propagandowe w językach niemieckim, angielskim i francuskim i koncentrowało wysiłki na promowaniu ideologii komunistycznej. Z kolei francuskie radio Le Poste Colonial [1931 r.], poprzednik Radia France International, miało zapewnić łączność Francji z jej posiadłościami kolonialnymi, a włoskie Radio Bari [1934 rok] było pierwszą rozgłośnią nadającą zagraniczne audycje w języku arabskim, tworzone z myślą o włoskich interesach w Afryce. W 1933 roku Adolf Hitler po dojściu do władzy przejął stację nadawczą w Zeesen koło Berlina, istniejącą od 1927 roku, która posiadała wówczas najwyższy maszt nadawczy na świecie oraz bardzo wysoką moc, i uczynił z niej czołową rozgłośnię propagandową narodowego socjalizmu, nazywaną również Radio Berlin. Programy nadawano na terytorium Afryki, Bliskiego i Środkowego Wschodu oraz Azji, można je było odbierać także w Europie. W audycjach krytykowano brytyjski imperializm i sytuację w brytyjskich koloniach, a także działania bolszewików. Ramówka rozgłośni wypełniona była ponadto programami o charakterze rozrywkowym - muzyką, kabaretami czy rozmowami na lżejsze tematy. Audycje te miały apolityczny charakter, ich celem było kreowanie pozytywnego wizerunku nazistów. Po konferencji w Monachium [1938 rok] głównym celem ataków stali się Żydzi, a audycje zaczęto nadawać po arabsku do świata arabsko-muzułmańskiego [do Turków, Irańczyków i Hindusów, Pakistańczyków i innych]. Według niektórych naukowców audycje te przyczyniły się do wzmocnienia postaw antysemickich w świecie muzułmańskim, tym bardziej, że prowadzili je ważni w hierarchii muzułmanie Yunus Bahri, Alimjan Idris, Taqi al-Din al-Hilali czy Wielki Mufta - Haj Amin El-Husseini ${ }^{10}$.

${ }^{9}$ P. Griset, La Société Radio-France dans l'entre-deux-guerres, "Histoire, économie \& société" 1983, t. 2, nr 2-1, s. 90.

${ }^{10}$ Zob. Ch. Hale, Hitler's Foreign Executioners: Europe's Dirty Secret, The History Press, wyd. e-book 2014, s. 265; wydanie polskie: Kaci Hitlera: brudny sekret Europy, przekł. M. Habura, 
Propagandowe użycie radia, służące dwudziestowiecznym przywódcom do zdobywania zwolenników w społeczeństwie oraz do zwalczania przeciwników politycznych i militarnych, stawiało radio w wymiarze hard power. Siła militarna i gospodarcza danego kraju, opieranie polityki wewnętrznej i zewnętrznej na „pokusach i groźbach”, jak określił hard power Joseph S. Nye Jr. ${ }^{11}$, były z powodzeniem rozpowszechniane na falach radiowych. Już wiele lat wcześniej Harold N. Graves Jr., pierwszy dyrektor [w latach 1941-1943] Foreign Broadcast Information Service, wydziału później włączonego do CIA, zajmującego się białym wywiadem, podkreślał - w swojej książce War on the Short Wave z 1941 roku - rolę radia w komunikowaniu międzynarodowym w sytuacji wojny. Graves Jr. przywołuje słowa amerykańskiego komentatora radiowego, sugerującego, że radio może być uznawane za „czwarty front wojenny” - obok frontu ekonomicznego, dyplomatycznego i militarnego. Graves Jr. uściślił, że to przede wszystkim propaganda jest owym „czwartym frontem”, ale znaczny wkład w jej rozpowszechnianie włożyło właśnie radio: „Radio poszerzyło pole walki na odległości dotąd niemożliwe do pokonania i uczyniło współczesny konflikt najbardziej rozgadaną wojną w historii" ${ }^{12}$. Programy radiowe, według tegoż autora, były kierowane do dwóch grup odbiorców: po pierwsze do obywateli państw sojuszniczych, a po drugie do obywateli państw neutralnych bądź „niewalczących”'13. Audycje radiowe miały przekonywać sojuszników do podejmowania jeszcze bardziej zaciekłej walki i do tego, że toczy się ona o wspólną sprawę, natomiast narody „niewalczące” należało przekonać, że powinny włączyć się do wojny po stronie aliantów lub przynajmniej nie podejmować działań sprzecznych z ich interesem. Audycje skierowane do obywateli wrogiego państwa miały przekonać, że przegrana ich armii jest bliska ${ }^{14}$.

Znane są liczne przykłady tego typu propagandy radiowej czasów II wojny światowej. Pierwszym przedsięwzięciem były audycje Radia-Stuttgart nadawane od 1939 roku na terytorium Francji, emitujące audycje w języku francuskim i angielskim. Najbardziej znanym prezenterem stał się francuski kolaborant Paul Ferdonnet, który tuż po rozpoczęciu wojny uciekł do Niemiec. W audycjach przekonywał, że jest francuskim patriotą, pragnącym otworzyć rodakom oczy na złe działania rządu premiera Édouarda Daladiera, który niepotrzebnie przystąpił

Społeczny Instytut Wydawniczy Znak, Kraków 2012; Zob. także: M. Küntzel, National Socialism and Anti-Semitism in the Arab World, ,Jewish Political Study Review” spring 2005, http://www. matthiaskuentzel.de/contents/national-socialism-and-anti-semitism-in-the-arab-world [dostęp: 10.05.2016].

${ }^{11}$ J.S. Nye Jr., Soft Power. Jak osiagnać sukces w polityce światowej, przekł. J. Zaborowski, Wydawnictwa Akademickie i Profesjonalne, Warszawa 2007, s. 34.

${ }^{12}$ H.N. Graves Jr., War on the Short Wave, The Foreign Policy Association, New York 1941, s. 7; tłum. M.W.Sz.

13 Tamże, s. 8.

14 Tamże, s. 17. 
do wojny z Niemcami i związał się sojuszem z Brytyjczykami. Choć Ferdonnet działał w kilkuosobowym zespole redakcyjnym, samodzielnie stał się symbolem czarnej propagandy, a francuska prasa i radio szybko okrzyknęły go „zdrajcą ze Stuttgartu"15. Kolejne Radio-Humanité - czerpiące z nazwy gazety wydawanej przez Francuską Partię Komunistyczną - od 1940 roku zachęcało do jednoczenia się ogólnoświatowego proletariatu, nie przeciw Niemcom, ale przeciw kapitalizmowi jako takiemu, pod przywództwem Związku Sowieckiego, ówczesnego sojusznika Niemiec, który miał gwarantować „nieagresję” Hitlera. Radiostacja La Voix de la Paix [Głos pokoju] atakowała rząd Daladiera, nazywając go „wojennym podżegaczem", natomiast rozgłośnia Réveil de la France [Przebudzenie Francji] odwoływała się do francuskich nacjonalistów ${ }^{16}$. Ponieważ hitlerowcy przejęli większość francuskich stacji nadawczych, w tym Radio-Paris [przemianowane na Radio Paris Mondiale], a nieliczne z pozostałych przeszły pod kontrolę rządu Vichy i marszałka Philippa Pétaina i działały jako Radio Nationale, francuski Ruch Oporu wraz z Charlesem de Gaullem rozpoczęli w 1940 roku nadawanie audycji z Londynu na antenie radia BBC. Mimo pomocy ze strony BBC, de Gaulle nie miał pełnej kontroli nad zawartością audycji w języku francuskim, które podlegały cenzurze brytyjskiej, zatem we wrześniu 1940 roku z Konga Francuskiego na terytorium francuskie zaczęły docierać audycje Radia Brazzaville, stworzonego na bazie istniejącego od 1935 roku Radia Club. Generał de Gaulle osobiście zlecił i nadzorował uruchomienie radia, które nazwał „La Voix de la France libre” - „głosem wolnej Francji”" 18 czerwca 1943 roku oddano do użytku nową antenę i siedzibę Radia Brazzaville, dzięki którym jego audycje mogły być słyszane w odległych krajach i stanowić przeciwwagę dla rozgłośni niemieckiego okupanta i kolaboracyjnego rządu Vichy.

Tuż po przystąpieniu do wojny rząd brytyjski zmonopolizował przepływ informacji w kraju; odtąd ich kontrolą i rozpowszechnianiem zajęło się Ministerstwo Informacji, które stworzyło podział na trzy kategorie informacji: informacje krajowe, zagraniczne i wojenne. Dział zagraniczny został dodatkowo podzielony na działy według kryteriów geograficznych: wspólnoty brytyjskiej, Europy oraz na północną i na południową strefę kontynentu amerykańskiego ${ }^{18}$. W dziale europejskim działała sekcja niemiecka, w której redakcjami kierowali obywatele brytyjscy biegle władający językiem niemieckim [politycy, naukowcy, dziennikarze]. Zarówno prasa, jak i radio BBC musiały zdać się na narzucony i kontrolowany [cenzurowany] obieg wiadomości. Poprawnego przebiegu audycji pilnował tzw.

${ }^{15}$ R.P. Scales, Radio and the Politics of Sound in Interwar France 1921-1939, Cambridge University Press, Cambridge 2016, s. 264-265.

${ }^{16}$ Tamże, s. 265.

${ }^{17}$ Musée de la Résistance 1940-1945, Inauguration du Nouvel Émetteur de Brazzaville, http://museedelaresistanceenligne.org/media2863-Inauguration-du-nouvel-A\#fiche-tab [dostęp: 15.05.2016].

${ }^{18}$ W. Kozaczuk, Wojna w eterze, Wydawnictwa Radia i Telewizji, Warszawa 1977, s. 107. 
switch censor, czyli osoba wyłączająca głośnik, gdy prezenterzy próbowali nadać treści niezatwierdzone przez cenzurę ${ }^{19}$. Co więcej, już w 1938 roku rząd brytyjski nakłonił kierownictwo agencji prasowej Reuters do podpisania kontraktu na odpłatne rozpowszechnianie - za pomocą swoich stacji nadawczych w Leafield i Rugby - informacji przygotowywanych przez Biuro Spraw Zagranicznych ${ }^{20}$, w pełni kształtując ich treść. Do audycji radiowych sekcji niemieckiej zatrudniano także rodowitych Niemców sprzeciwiających się Hitlerowi: jednym z nich był wybitny prozaik, laureat literackiej nagrody Nobla w 1929 roku, Tomasz Mann.

Mimo dużej słuchalności Radia BBC w Europie, Brytyjczycy nie zaniechali czarnej propagandy i uruchomili Radio Gustav Siegfried Eins [GSI], pod przewodnictwem Seftona Delmera, wywodzącego się z sekcji niemieckiej BBC i znanego dziennikarza „Daily Express”, który stał się twórcą radiowej propagandy brytyjskiej podczas II wojny światowej ${ }^{21}$. Zadaniem rozgłośni było tworzenie audycji skierowanych do żołnierzy i obywateli niemieckich, które miały sprawiać wrażenie, że są nadawane przez tajne ugrupowanie Wermachtu, wierne samemu Hitlerowi, ale przeciwne czołowym działaczom Socjaldemokratycznej Partii Niemiec, którzy rzekomo sprzeniewierzali się idei nazizmu. Programy zawierały zarówno treści jawne, jak i szyfrowane, a emisje prowadzono w taki sposób, aby sugerować nadawanie rozszczepionego sygnału do poszczególnych komórek tajnego ugrupowania ${ }^{22}$. Audycje prowadził tzw. der Chef [Szef], w rzeczywistości antyfaszysta, niemiecki emigrant - Peter Secklmann, znany jako Paul Sanders ${ }^{23}$. Celem audycji była dezinformacja wywiadu niemieckiego, stąd użycie łatwych do odczytania szyfrów w komunikatach wprowadzających w błąd, a także podważenie wiarygodności niemieckich oficerów w opinii niemieckich żołnierzy i cywilów. Audycje zawierały najnowsze doniesienia z frontów wojny; o sytuacjach z resortów wojskowych i cywilnych w Niemczech; o nadużyciach dygnitarzy cywilnych i wojskowych, włączając informacje o ich życiu prywatnym:

Wywlekano na światło dzienne nie tylko sprawy polityczne czy ekonomiczne, ale także - gdy posiadano odpowiednie informacje - ich życie osobiste, intymne. [...] wymieniano z nazwiska hitlerowców mających faktyczne czy tylko domniemane skłonności do perwersji, fetyszyzmu, itp. ${ }^{24}$

W programach odnoszono się do problemów niemieckiej ludności cywilnej, np. z zaopatrzeniem, często wskazując na nierówne traktowanie „Zwykłych”

\footnotetext{
19 Tamże, s. 109.

${ }^{20}$ J. Wood, dz. cyt., s. 55.

${ }^{21}$ W. Kozaczuk, dz. cyt., s. 110.

22 Tamże, s. 121.

23 Tamże, s. 123.

${ }^{24}$ Tamże, s. 129.
} 
Niemców przy podziale towarów ${ }^{25}$. Rozgłośnia pozyskiwała informacje $\mathrm{z}$ niemieckiej prasy, ich źródło stanowiły także listy wysyłane z okupowanej Europy do Ameryk Północnej i Południowej, przechwytywane przez brytyjską cenzurę wojskową, ponadto z urządzeń podsłuchowych zakładanych w obozach dla niemieckich jeńców wojennych, a także z akcji wywiadowczych brytyjskiej marynarki wojennej ${ }^{26}$.

Odpowiedzią Niemców były audycje z udziałem tzw. Lorda Haw-Haw, czyli Williama Joyce'a, obywatela USA irlandzkiego pochodzenia o faszystowskich poglądach, którego propagandowe audycje nadawało od 1939 roku niemieckie radio z Hamburga. Cieszyły się one sporą popularnością, ponieważ Joyce przekazywał relacje z walk wojennych - wówczas przegrywanych przez aliantów - inaczej przedstawianych niż w radiu BBC, co czyniło go wiarygodnym w oczach Brytyjczyków. W czerwcu 1940 roku Niemcy przejęli Radio Luxembourg [założone w 1933 roku], najmocniejszą stację nadawczą tamtych czasów, która w 1935 roku posiadała 50\% słuchalności w Europie, co można było przeliczyć na 4 mln słuchaczy, z których połowa pochodziła z Wielkiej Brytanii ${ }^{27}$. Niemcy do 1944 roku na paśmie Radia Luxembourg nadawali audycje propagandowe skierowane głównie do słuchaczy brytyjskich, którzy także na jego falach mogli usłyszeć audycje prowadzone przez Lorda Haw-Haw. Niemcy przejmowali każdą rozgłośnię w kolejno podbijanych krajach, w konsekwencji już w lecie 1940 roku dysponowali największą siecią radiową na świecie ${ }^{28}$. Warto również wspomnieć o Żołnierskim Radiu Belgrad [Soldatensender Belgrad], zwanym „Lili Marleen”, wykorzystywanym przez niemieckie oddziały Afrika Korps. Stacja - służąca do propagandy antybrytyjskiej - zyskała popularność i „drugie imię” za sprawą piosenki o tym samym tytule. Utwór powstał na bazie wiersza Hansa Leipa z czasów Wielkiej Wojny [muzykę skomponował w 1937 roku Norbert Schultze]. W latach 1939-1944 wykonywany był przez Lale Andersen, od 1944 roku przez Marlenę Dietrich, stając się ulubioną piosenką wojenną zarówno niemieckich, jak i brytyjskich żołnierzy walczących w Afryce ${ }^{29}$. Radio „Lili Merleen” było przykładem wykorzystania kultury popularnej - poza propagandą oczywiście - do osłabienia morale żołnierzy przeciwnej armii, ale też do wytworzenia z nimi specyficznej więzi i zniechęcenia ich do ataków na dotychczasowego wroga.

Podobną propagandową działalność prowadziła Tokijska Róża - Tokyo Rose - faktycznie Iva Togura - spikerka o amerykańsko-japońskich korzeniach, kie-

${ }^{25}$ Zob. tamże, s. 128.

${ }^{26}$ Zob. tamże, s. $130-131$.

${ }^{27}$ Zob. J. Wood, dz. cyt., s. 44.

${ }^{28}$ Zob. tamże, s. 67. Por.: J.S. Berg, The Early Shortwave Stations: A Broadcasting History Through 1945, McFarland \& Company, Jefferson-London 2013, s. 198; W. Kozaczuk, dz. cyt., s. 78.

${ }^{29}$ Zob. J. Wood, dz. cyt., s. 69. Zob.: J. Roszkowski, Piosenka ponad frontami, „Polityka” 2006, nr 45 , s. $82-84$. 
rująca prowadzone przez siebie audycje w japońskim radiu NHK do amerykańskich żołnierzy, którzy od ataku Japończyków na amerykańskie bazy wojskowe w Pearl Harbour stacjonowali w obszarze Południowego Pacyfiku. Audycje o nazwie "Zero Hour” [„Godzina Zero”] miały imitować styl amerykańskich rozgłośni radiowych, aby przyciągać uwagę żołnierzy armii USA, a Iva Togura miała wabić ich swoim atrakcyjnym głosem. Programy składały się ze stałych elementów: muzycznej czołówki pt. Strike Up the Band, granej przez Bostońską Orkiestrę Popularną [Boston Pops Orchestra ${ }^{30}$ ], listów amerykańskich jeńców wojennych czytanych na antenie, odcinków słuchowiska dla dzieci The Orphan Annie Show, opartego na popularnej książeczce o przygodach sierotki Ani, wieści z amerykańskich frontów wojennych, szafy grającej - audycji z muzyką jazzową, serwisów informacyjnych oraz wojskowej muzyki marszowej ${ }^{31}$. Tajemnicą dla słuchających audycji amerykańskich żołnierzy pozostawał fakt, że audycję nadawała rozgłośnia japońska. A żeńskich głosów - poza Tokyo Rose - użyczały inne prezenterki posługujące się równie poetyckimi pseudonimami: wspomniana Orphan Annie [Sierotka Anna], Manila Rose [Róża Manili], The Nightingale of Nanking [Słowik z Nanking]. Japończycy słusznie uznali, że kobiece głosy lepiej podziałają na wyobraźnię samotnych żołnierzy. W konstruowaniu tego typu programów częściej posługiwano się szarą propagandą, stąd zatajanie prawdziwego nadawcy audycji, ale i obecność treści manipulujących emocjami słuchaczy.

Wraz z przystąpieniem USA do wojny światowej rząd amerykański zdecydował o utworzeniu własnej sieci radiowej, nadającej na obszarze Europy, a z czasem na terytorium wielu kolejnych państw na wszystkich kontynentach. 1 lutego 1942 roku powstał Głos Ameryki - Voice of America ${ }^{32}$. Podlegał on kierownictwu Office of War Information [Biura Informacji Wojennej] - OWI ${ }^{33}$, choć przeznaczony był przede wszystkim dla słuchaczy cywilnych. Głównym celem stacji było prezentowanie głosu rządu amerykańskiego na świecie. Pierwszymi językami, w jakich nadawano audycje w VOA, były niemiecki i turecki, powołano także odpowiadające im sekcje: niemiecką i turecką. Następnego dnia założono kolejne redakcje: afrykańską, duńską, fińską, flamandzką, francuską [przeznaczoną dla Francji], japońską, norweską, perską i włoską. Kilka dni później rozpoczęła nadawanie sekcja arabska, w marcu sekcje angielska, czechosłowacka i tajska, w maju polska, później kolejne. Programy składały się z głównie z muzyki, aktualnych informacji, komentarzy i programów rozrywkowych pochodzących

\footnotetext{
${ }^{30}$ Jedna z najsłynniejszych wówczas i obecnie orkiestr amerykańskich, prowadzona przez wybitnych dyrygentów, m.in. Arthura Fiedlera i Johna Williamsa, istniejąca do dziś. Więcej: A Brief History of the Boston Pops, http://www.bso.org/brands/pops/about-us/historyarchives/the-history-of-the-boston-pops.aspx [dostęp: 23.05.2016].

${ }^{31}$ Zob. J. Wood, dz. cyt., s. 89.

${ }^{32}$ Voice of America, VOA History, http://www.insidevoa.com/p/5829.html [dostęp: 23.05.2016].

${ }^{33}$ Zob. J. Wood, dz. cyt., s. 75.
} 
z amerykańskich rozgłośni, a także programów przygotowywanych samodzielnie przez redaktorów VOA ${ }^{34}$. Wojenne audycje radiowe Głosu Ameryki przyczyniły się w niemałym stopniu do wytworzenia wśród Europejczyków przychylnej postawy wobec USA, a przede wszystkim sympatii do narodu amerykańskiego i - co oczywiste - do upowszechnienia amerykańskiej kultury popularnej. Departament Wojny USA, wkrótce po powstaniu VOA, utworzył wojskowy serwis zagraniczny skierowany z kolei głównie do własnych żołnierzy, ale i sojuszników oraz wrogów - 29 maja 1942 roku założono Armed Forces Radio Service - AFRS - Radio Sił Zbrojnych ${ }^{35}$. Była to agencja odpowiedzialna za produkcję, zakup i rozpowszechnianie programów radiowych, które nadawano na falach rozgłośni należących do armii amerykańskiej, rozmieszczonych na całym świecie i działających w sieci AFN - American Forces Network. AFRS oprócz programów tworzonych samodzielnie emitowała audycje kupione od amerykańskich sieci radiowych - ABC, CBS, MBC i NBC. Rozgłośnie nadawały przemówienia prezydenta, sekretarzy: stanu, wojny i marynarki wojennej, a także wszystkich wysokich rangą urzędników cywilnych i wojskowych. Ponadto emitowano programy popularnonaukowe [cykl „Science Magazine of the Air”], informacyjno-edukacyjne [„Heard at Home”, „Our Foreign Policy”], rozrywkowe z udziałem gwiazd teatru, filmu i radia [„Command Performance”, „Jubilee”] i reportaże o aktualnych zdarzeniach [,This Is the Story”] ${ }^{36}$.

Podczas gdy działalność programową takich stacji, jak Radio-Stuttgard, Gustav Siegfried Eins czy Radio Nationale można zaliczyć do czarnej propagandy, czyli hard power, to audycjom o charakterze rozrywkowo-edukacyjnym emitowanym na falach Radia BBC Empire Service, Voice of America i amerykańskich wojskowych rozgłośni AFRS, bliżej było do stosowania soft power w nadawczości radiowej jako uzupełnienie „twardej siły” w polityce zagranicznej. Celem tych audycji było bowiem ocieplenie, poprawienie wizerunku danego państwa czy narodu poprzez prezentację jego kulturalnych atrybutów i idei politycznych. W mojej ocenie to właśnie radio za pomocą tego typu audycji zapoczątkowało rozwój dyplomacji publicznej jako nowej formy komunikowania międzynarodowego. Za sprawą rozgłośni dla zagranicy do komunikowania międzynarodowego

${ }^{34}$ Zob. Ch.H. Sterling, J.M. Kittross, Stay Tuned: A History of American Broadcasting, Lawrence Erlbaum Associates, Mahwah New Jersey 2002, s. 263.

${ }^{35}$ B. Lewandowski, Propaganda radiowa USA: zastosowanie radia $w$ propagandzie na kraje socjalistyczne, Państwowe Wydawnictwo Naukowe, Warszawa 1981, s. 103. Zagadnienia związane z mediami wojskowymi USA omawiam szerzej w artykule pt. Media $w$ stużbie sit zbrojnych. Polityka informacyjna Departamentu Obrony USA - zarys zagadnienia, [w:] Mediatyzacja komunikowania politycznego. W kręgu badań politologicznych i medioznawczych, red. M. Adamik-Szysiak, Wydawnictwo Uniwersytetu Marii Curie-Skłodowskiej, Lublin 2015, s. 153-170.

${ }^{36}$ Radio Platters - Troop Information Tools, „Army Information Digest” czerwiec 1946, vol. 1, no. 2, s. 24-25, http://babel.hathitrust.org/cgi/pt?id=uc1.b3019680;view=lup;seq=20 [dostęp: 14.05.2016]. 
została włączona publiczność, która nasłuchując nieocenzurowanych informacji i ulubionych programów, zyskała możliwość oceny swojego położenia społeczno-politycznego z szerszej perspektywy i stała się wyrazicielem międzynarodowej opinii publicznej.

Po II wojnie światowej rozgłośnie europejskie przejęte przez nazistów wróciły w ręce władz wyzwolonych państw, natomiast podziemne stacje dywersyjne zostały zlikwidowane lub włączone do odradzających się radiofonii państwowych. Istniejące radiostacje międzynarodowe kontynuowały działalność, choć często w nowej formule, powstały też kolejne - sytuacja geopolityczna wymagała bowiem prowadzenia dalszych działań propagandowych w eterze. Rozgłośnie Voice of America, BBC World Service, Radio Wolna Europa/Radio Swoboda [Liberty], Deutsche Welle, Radio France International, Radio Marti, Radio Canada International i inne przyjęły na siebie rolę „posłanników prawdy”. Aktywność Zachodu koncentrowała się na wskazywaniu totalitarnego wymiaru komunizmu i dominacji Związku Sowieckiego oraz przyrównywaniu komunizmu do nazizmu. Z drugiej strony propaganda państw komunistycznych realizowana na antenach Radia Moskwa, Radia Pekin oraz innych - atakowała zachodni kapitalizm za złe położenie robotników i imperializm. Ale rozgłośnie zachodnie - poza dostarczaniem informacji o wydarzeniach wewnętrznych krajów, do których kierowano serwisy informacyjne nadawane w ich językach - stały się także nośnikiem zachodniego stylu życia, który okazał się atrakcyjny dla wschodnich odbiorców radia z zagranicy. Treści lżejszego formatu i muzyka rozrywkowa - od jazzu, bluesa czy rock'n'rolla aż po rock - podbijały serca słuchaczy na całym świecie w czasach zimnej wojny. Słowa Michaela Nelsona:

Dlaczego Zachód wygrał zimną wojnę? Nie przy użyciu broni. To nie broń przełamała żelazną kurtynę. Zachodnia inwazja to było radio, które okazało się lepsze od miecza: prawdziwym szczytem osiągnięć jest podbicie armii wroga bez walki ${ }^{37}$

najlepiej oddają rolę radia w tamtym czasie jako instrumentu soft power.

$\mathrm{Z}$ czasem, wraz ze zmieniającą się powojenną sytuacją międzynarodową, propaganda $\mathrm{w}$ radiu zaczęła ustępować miejsca treściom kulturalnym, społecznym, promującym światowy pokój, wartości demokratyczne i prawa człowieka. $\mathrm{W}$ ten sposób hard power w radiu zostało prawie całkowicie wyparte przez soft power, które stanowi „siłę przyciągania i uwodzenia”38. Jest formą przekonywania do własnych racji, włączania innych do własnego systemu wartości czy działań w jakiejś dziedzinie, poprzez przekonanie innych podmiotów o słuszności

${ }^{37}$ M. Nelson, War of the Black Heavens, London-Washington 1997, cyt. za: M. Maliszewski, Deutsche Welle w systemie medialnym Republiki Federalnej Niemiec, Oficyna Wydawnicza ASPRA-JR, Warszawa 2012, s. 31.

38 J.S. Nye Jr., dz. cyt., s. 34-35. 
swoich zasad czy przedsięwzięć, jednak bez używania mechanizmów opartych na manipulacji czy dezinformacji. Soft power oparta jest na ,atrakcyjności kultury danego kraju, ideałów politycznych i realizowanej polityki"39. Zatem to kultura, wartości polityczne oraz działania w zakresie polityki, także zagranicznej, są zasobami miękkiej siły. Radio jest idealnym ich nośnikiem.

Soft power jest częścią dyplomacji kulturalnej - dziedziny polityki międzynarodowej, odpowiadającej za promowanie własnej kultury za granicą. Dyplomacja kulturalna, w węższym ujęciu, służy realizacji określonych interesów społeczno-kulturalnych czy też polityczno-ekonomicznych. W szerszym ujęciu może być formą międzynarodowej współpracy w upowszechnianiu systemu wartości opartego na poszanowaniu praw jednostki i w celu utrzymania światowego pokoju, z uwzględnieniem różnorodności kulturowej współistniejących społeczności międzynarodowych. Institute for Cultural Diplomacy [ICD], istniejący od 1999 roku, definiuje dyplomację kulturalną w następujący sposób:

Dyplomacja kulturalna może najlepiej być opisana jako kierunek działań, które polegają na wymianie idei, wartości, tradycji i innych aspektów kultury lub tożsamości, w celu wzmocnienia wzajemnych relacji, rozszerzenia współpracy społeczno-kulturalnej lub promowania narodowych interesów; Dyplomacja kulturalna może być realizowana zarówno przez sektor publiczny, sektor prywatny, jak i społeczeństwo obywatelskie ${ }^{40}$.

Celami dyplomacji kulturalnej według ICD są szacunek i uznanie różnorodności kulturowej i dziedzictwa, globalny dialog międzykulturowy; sprawiedliwość, równość i współzależność; ochrona Międzynarodowych Praw Człowieka; globalny pokój i stabilizacja ${ }^{41}$. Dyplomacja kulturalna nie wyklucza zatem stosowania „białej propagandy” jako jawnej formy perswazji, spełnia ona bowiem warunek niezbędny soft power - „opiera się na zdolności kształtowania preferencji innych"42.

Posługiwanie się białą propagandą przez zachodnie rozgłośnie międzynarodowe można przypisać założeniom soft power - za pomocą programów radiowych miały „przekonać i uwieśc” słuchaczy z państw socjalistycznych do wartości Zachodu. Warto nadmienić, że niekiedy i w ich programach zamieszczano przekazy, które zakwalifikować można do propagandy szarej, czyli takiej, w której źródło informacji nie jest precyzyjnie określone, a podawane informacje nie są zbyt dokładne i mogą wprowadzać w błąd. Przykładem były próby dezinfor-

\footnotetext{
39 Tamże, s. 25.

${ }^{40}$ Institute for Cultural Diplomacy [ICD], What is Cultural Diplomacy?, http://www.culturaldiplomacy.org/index.php?en_culturaldiplomacy [dostęp: 10.05.2016]; tłum. M.W.Sz.

${ }^{41}$ Zob. tamże.

42 J.S. Nye Jr., dz. cyt., s. 34.
} 
mowania opinii publicznej przez Radio Moskwa na temat wojny w Afganistanie, w której od 1979 roku ZSRS brało udział, a także przeciwstawne działania Głosu Ameryki ${ }^{43}$. Kontrowersyjne okazało się także ukrywanie faktu, że Radio Wolna Europa i Radio Swoboda były współfinansowane przez amerykański rząd i nadzorowane przez CIA, jednak współcześnie znane już są powody, dla których te informacje utrzymywano w tajemnicy. Wiadomo także, że mimo to, stacje radiowe cieszyły się dużą autonomią i swobodą programową, a amerykański nadzór i finansowanie obu rozgłośni nie wpłynął zasadniczo na pełnioną przez nie rolę „zastępczego radia”44. Ta rola „zastępczego radia”, polegająca na zastępowaniu rodzimych rozgłośni danego kraju - cenzurowanych i zależnych od rządu - w dostarczaniu obywatelom tych krajów prawdziwych, obiektywnych i rzetelnych informacji o sprawach wewnętrznych oraz międzynarodowych, przypadła wszystkim rozgłośniom zachodnim nadającym dla zagranicy. Ich audycje obejmowały zasięgiem kraje komunistyczne Europy Wschodniej, a także spoza Europy m.in. Chiny, Wietnam, Kambodżę czy Kubę.

Badania nad komunikowaniem międzynarodowym sytuują rozwój dyplomacji publicznej wraz z nastaniem zimnej wojny, a jej intensywny rozwój przypisuje się głównie kanałom telewizji międzynarodowej w latach 80. Przyjęta przez mnie perspektywa historyczna i omówienie przykładów z okresu II wojny światowej pozwala prześledzić drogę od hard power do soft power w nadawczości radiowej i wykazać, że zjawisko włączania publiczności międzynarodowej, głównie cywilnej, do polityki zagranicznej państw - czyli rozwój dyplomacji publicznej - rozpoczęło się o wiele wcześniej - już podczas II wojny światowej - i że zapoczątkowano je za pomocą radia. Szczególnym przypadkiem stał się Głos Ameryki [1942 rok], którego celem nadawczym stało się właśnie kształtowanie międzynarodowej opinii publicznej i tworzenie pozytywnego wizerunku USA, bez stosowania manipulacji i dezinformacji ${ }^{45}$.

Współcześnie audycje rozgłośni zagranicznych zawierające serwisy informacyjne dotyczące poszczególnych krajów, słuchowiska literackie, programy kulturalne i publicystyczne, prezentujące nieocenzurowane treści, również te, które są niedostępne w rodzimych, oficjalnych przekazach medialnych, nadal są

${ }^{43}$ Więcej na ten temat zob.: B. Dobek-Ostrowska, J. Fras, B. Ociepka, Teoria i praktyka propagandy, Wydawnictwo Uniwersytetu Wrocławskiego, Wrocław 1999, s. 33.

${ }^{44}$ Więcej na ten temat zob.: A. Ross Johnson w: Radio Wolna Europa i Radio Swoboda. Lata CIA i późniejsze, przekł. A. Borzym, Kolegium Europy Wschodniej, Wrocław 2014 oraz A. Puddington, Rozgłośnie Wolności. Tryumf Radia Wolna Europa i Radia Swoboda w zimnej wojnie, przekł. A. Borzym, Wydawnictwo Naukowe Uniwersytetu Mikołaja Kopernika, Toruń 2009.

${ }^{45}$ Te założenia nie zawsze mogły być realizowane, niekiedy w programach stosowano szarą propagandę, a kolejni prominentni politycy w USA wielokrotnie ponawiali próby nacisku na redakcję VOA. Zob. A.L. Heil Jr., Voice of America: A History, Columbia University Press, New York 2003; J. Semelin, Wolność w eterze, przekł. H. Abramowicz, Wydawnictwo Uniwersytetu Marii Curie-Skłodowskiej, Lublin 1999. 
ważnym elementem soft power w dyplomacji publicznej państw demokratycznych. Po zakończeniu zimnej wojny rozgłośnie tego typu przedefiniowały swoje sposoby działania, tym bardziej, że pojawili się poważni konkurenci medialni: telewizja międzynarodowa i Internet; a także zmodyfikowały kierunki nadawania - zbieżne $\mathrm{z}$ aktualną polityką zagraniczną danego rządu. Podstawowym celem rozgłośni międzynarodowych pozostaje rozpowszechnianie idei, takich jak demokracja, wolności obywatelskie i prawa człowieka oraz popularyzowanie kultury danego kraju - główne filary soft power. Wciąż jednak istnieją stacje, np. reaktywowane Radio Sputnik, których głównym zadaniem jest dezinformacja i manipulacja - filary hard power.

\section{Bibliografia}

Berg J.S., The Early Shortwave Stations: A Broadcasting History Through 1945, McFarland \& Company, Jefferson-London 2013.

Dobek-Ostrowska B., Fras J., Ociepka B., Teoria i praktyka propagandy, Wydawnictwo Uniwersytetu Wrocławskiego, Wrocław 1999.

Graves Jr. H.N., War on the Short Wave, The Foreign Policy Association, New York 1941.

Griset P., La Société Radio-France dans l'entre-deux-guerres, "Histoire, économie \& société" 1983, t. 2, nr 2-1.

Hale Ch., Hitler's Foreign Executioners: Europe's Dirty Secret, The History Press, wyd. e-book 2014.

Heil Jr. A.L., Voice of America: A History, Columbia University Press, New York 2003.

Johnson A.R., Radio Wolna Europa i Radio Swoboda. Lata CIA i późniejsze, przekł. A. Borzym, Kolegium Europy Wschodniej, Wrocław 2014.

Kozaczuk W., Wojna w eterze, Wydawnictwa Radia i Telewizji, Warszawa 1977.

Levinson P., Miękkie ostrze, czyli historia i przyszłość rewolucji informacyjnej, przekł. H. Jankowska, Wydawnictwo Muza SA, Warszawa 2006.

Lewandowski B., Propaganda radiowa USA: zastosowanie radia $w$ propagandzie na kraje socjalistyczne, Państwowe Wydawnictwo Naukowe, Warszawa 1981.

Maliszewski M., Deutsche Welle w systemie medialnym Republiki Federalnej Niemiec, Oficyna Wydawnicza ASPRA-JR, Warszawa 2012.

Nahin P.J., The Science of Radio, Springer Science \& Business Media, New York 2001.

Nye Jr. J.S., Soft Power. Jak osiagnąć sukces w polityce światowej, przekł. J. Zaborowski, Wydawnictwa Akademickie i Profesjonalne, Warszawa 2007.

Puddington A., Rozgłośnie Wolności. Tryumf Radia Wolna Europa i Radia Swoboda w zimnej wojnie, przekł. A. Borzym, Wydawnictwo Naukowe Uniwersytetu Mikołaja Kopernika, Toruń 2009.

Scales R.P., Radio and the Politics of Sound in Interwar France 1921-1939, Cambridge University Press, Cambridge 2016.

Semelin J., Wolność w eterze, przekł. H. Abramowicz, Wydawnictwo Uniwersytetu Marii Curie-Skłodowskiej, Lublin 1999.

Sterling Ch.H., Kittross J.M., Stay Tuned: A History of American Broadcasting, Lawrence Erlbaum Associates, Mahwah New Jersey 2002. 
Wielopolska-Szymura M., Media w stużbie sit zbrojnych. Polityka informacyjna Departamentu Obrony USA - zarys zagadnienia, [w:] Mediatyzacja komunikowania politycznego. W kręgu badań politologicznych i medioznawczych, red. M. Adamik-Szysiak, Wydawnictwo Uniwersytetu Marii Curie-Skłodowskiej, Lublin 2015.

Wood J., History of International Broadcasting, Peter Peregrinus Ltd., London 1994.

\section{Netografia}

A Brief History of the Boston Pops, http://www.bso.org/brands/pops/about-us/historyarchives/the-history-of-the-boston-pops.aspx [dostęp: 23.05.2016].

Adamkowicz M., Eksponaty z Muzeum Poczty Polskiej. Aparat zwany juzem czyli historia telegrafu Hughesa, http://www.dziennikbaltycki.pl/artykul/970141,eksponaty-z-muzeum-poczty-polskiej-aparat-zwany-juzem-czyli-historia-telegrafu-hughesa,id,t.html [dostęp: 14.05.2016].

David Hughes, http://www.britannica.com/biography/David-Hughes [dostęp: 12.05.2016].

Franklin D. Roosvelt Presidential Library and Museum, http://docs.fdrlibrary.marist.edu/firesi90. html [dostęp: 14.05.2016].

Institute for Cultural Diplomacy [ICD], What is Cultural Diplomacy?, http://www.culturaldiplomacy.org/index.php?en_culturaldiplomacy [dostęp: 10.05.2016].

Küntzel M., National Socialism and Anti-Semitism in the Arab World, „Jewish Political Study Review" spring 2005, http://www.matthiaskuentzel.de/contents/national-socialism-and-anti-semitism-in-the-arab-world [dostęp: 10.05.2016].

Musée de la Résistance 1940-1945, Inauguration du Nouvel Émetteur de Brazzaville, http:// museedelaresistanceenligne.org/media2863-Inauguration-du-nouvel-A\#fiche-tab [dostęp: 15.05.2016].

Radio Platters - Troop Information Tools, „Army Information Digest” czerwiec 1946, vol. 1, no. 2, s. 24-25, http://babel.hathitrust.org/cgi/pt?id=uc1.b3019680; view=1up;seq=20 [dostęp: 14.05.2016]

Voice of America, VOA History, http://www.insidevoa.com/p/5829.html [dostęp: 23.05.2016].

Mirosława Wielopolska-Szymura

\section{Radio abroad - from hard power to soft power in international radio broadcasting}

\section{(Summary)}

Shortly after its invention, radio began to be used for political broadcasting with an international range. It was used to exercise power at a distance, sending messages to overseas diplomatic outposts or colonial territories. In the inter-war period it became an instrument of propaganda, and during the II World War the countries engaged in the conflict began to broadcast propaganda to listeners abroad, trying to bring them to their way of thinking. Simultaneously, you could observe a change in the approach to the international use of radio. It was regarded that radio programmes didn't have to be used for disinformation and manipulating foreign listeners, but that it could aid in building a positive image of a given country, by basing the messages on genuine information 
and presenting the country's cultural attractions, as well as cultivating a positive opinion among among listeners abroad. In consequence the stations and programmes that emerged and which utilised soft power - in international communications, which was the impulse behind the development of a new public diplomacy treating the recipient of the message - the overseas public - as the object of the communicative process.

Keywords: international radio, II World War, propaganda, public diplomacy. 